Çukurova Üniversitesi Mühendislik Mimarlık Fakültesi Dergisi, 29(2), 95-113 ss., Aralık 2014

Çukurova University Journal of the Faculty of Engineering and Architecture, 29(2), pp. 95-113, December 2014

\title{
PVC ve PET Atıkların Seçimli Flotasyonu Bölüm 2: Laboratuar ve Pilot Ölçekli Kolon Testleri
}

\author{
Mert KILIÇ ${ }^{1}$, A. Ekrem YÜCE ${ }^{* 2}$ \\ ${ }^{I}$ Troia Madencilik Ltd. Şti. Hurmaköy No:14 Çan/Çanakkale \\ ${ }^{2}$ İTÜ, Maden Fakültesi, Cevher Hazırlama Mühendisliği Bölümü, Maslak / İstanbul
}

Geliş tarihi: 18.10.2014 Kabul tarihi:3.12.2014

\section{Özet}

Plastiklerin doğada uzun süre kalarak çevre kirliliğindeki ciddi tehlikelerden biri olması ve dünya plastik tüketiminin giderek artması, bu maddelerin geri dönüşümünü gündeme getirmiştir. Geri kazanımı üzerinde durulan en önemli iki plastik türü Polietilen Teraftalat (PET) ve Polivinil Klorür (PVC)'dür. Plastiklerin yoğunlukları birbirine yakın olduğu için, gravite yöntemleri ile ayrılması söz konusu değildir, fakat yüzey özelliklerinden yararlanılarak PET ve PVC'den biri hidrofilik yapılıp bastırılırken diğerinin yüzdürülerek köpükle alınması mümkündür. Flotasyon ile ayırmada; doğal hidrofobik (su sevmez) olan plastiklerden; hidrofilik (su sever) olması istenen plastiğin yüzeyi plastikleştirici reaktifler kullanılarak değiştirilir.

Araştırmalar sırasında ilk olarak; PET ve PVC nin birbirinden ayrılabileceği parametreleri belirlemek için laboratuar tipi kolon flotasyonu ünitesi kullanılmıştır. Daha sonra, laboratuar ölçekte elde edilen ayırma parametrelerinin 1şığında, pilot ölçekli kolon ünitesi kullanılarak, PET ve PVC'nin selektif olarak ayırılabildiği koşullar belirlenmiştir. Tüm deney parametrelerinin optimizasyonu ile elde edilen sonuçlara göre; \%95,5 içerikli bir PET ürünü \%92,3 verimle yüzdürülürken (köpükte), \%99,4 içerikli bir PVC'nin ise \% 90,1 verimle batan ürün olarak ayrılabileceği belirlenmiştir.

Anahtar Kelimeler: PET, PVC, Kolon flotasyonu, Plastikleştirici, Lignin alkali

\section{Selective Flotation of PVC and PET Wastes Part 2: Laboratory and Pilot Scale Column Flotation Tests}

\begin{abstract}
The lifespan of plastics is far too long and they cause serious environmental threats. Moreover, worldwide consumption of these materials increases day by day. These facts leave the world no choice but recycling the used and waste plastics. Since various kinds of plastics with different chemical structure appear in markets, each type should be separated from others in order to make reusing possible after recycling. Among this variety, two types of plastics have been received high attention and interest; namely polyethylene terephthalate (PET) and polyvinyl chloride (PVC).
\end{abstract}

\footnotetext{
* Yazışmaların yapılacağı yazar: Mert KILIÇ, Troia Madencilik Ltd. Şti. Hurmaköy No:14 Çan/Çanakkale.mertkilic95@hotmail.com
} 


\begin{abstract}
Although one of the widely used methods in recycling plants is gravity separation techniques; this method is not applicable in case of PVC and PET separation as the density of both is too close. Another alternative way for these plastics is to separate them based on their surface characteristics and properties. By rendering the surface of one more hydrophobic using proper collector surfactant, it is possible to collect it in froth zone through flotation process while the other one remains hydrophilic and settles down.
\end{abstract}

In this study, to reveal the separation parameters of PET and PVC a laboratory scale column froth flotation cell was used. Established parameters were then used in flotation experiments in pilot scale in order to find the best conditions for selective separation of PET and PVC. Based on the results obtained after optimization of all experimental parameters, high grade PET concentrate of $95,5 \%$ with recovery of $92,3 \%$ was acquired in froth phase and PVC of $99,4 \%$ in grade with recovery of $90,1 \%$ was obtained in settling.

Key Words: PET, PVC, Column flotation, Plasticizier, Lignin alkaly

\section{GIIRIS}

Plastikler, petrol ve doğal gaz gibi doğal kaynaklardan elde edilen hidrokarbonların kullanımı ile üretilmektedir. Bir başka deyişle, monomerlerin kimyasal bağlarındaki değişiklik ile polimerlere dönüşmesi sonucunda plastikler elde edilmektedir. Plastikler, termoplastikler ve termosetler olmak üzere iki temel tiptedir. Plastiklerin özelliklerini, polimer molekülün yapısı ve büyüklüğü belirler. Termoplastikler, 1sitılınca yumuşarlar ve soğutulduklarında tekrar sertleşirler. Termosetler ise bir defa kalıplandıktan sonra asla yumuşamazlar. Plastikler toz, granül, kepek ve çözelti şeklinde olabilmektedir. Katı maddelerin 1sı ve basınç ile muamele edilmesi sonucunda günlük hayatımızda yakından tanıdığımız birçok ürün üretilmektedir [1].

Katı atıklardan plastiklerin geri kazanılması günümüzde en dikkat çeken çevre konularından birisidir. Bu çalışmaların kapsamında özellikle şişe uygulamaları nedeniyle PVC'nin giderek önem kazanan ayrı bir yeri bulunmaktadır. Katı atıklar içerisinde yer alan plastiklerin diğer bir bölümünü oluşturan film halindeki plastik atıklarda da ayırma işlemi söz konusudur. Bunun için iri parçalar halinde kesilen atıklar önce titreşimli banttan sonra bir mıknatıstan geçirilmekte; daha sonra çöktürme tankına gönderilmektedir. Böylece, kirleticilerden temizlendikten sonra malzeme ayırım işlemine geçilmektedir. Bunun için de genellikle flotasyon ve hidrosiklon yöntemleri kullanılmaktadır. Elde edilen ürünler kurutulduktan sonra peletlenerek pazarlanmaktadır [2].

Günlük hayatta kulanılan plastik şişelerin en yaygın görülen çeşitleri Polietilen Teraftalat (PET) ve Polivinil Klorür (PVC)'dür. Geri kazanılan PET'in içerisindeki PVC'nin varlığı; PVC'nin bozulması esnasında mikro moleküller sayesinde gelişen hidroklorik asidin zincir bölünmesi nedeniyle çok tehlikelidir. PVC'nin ortama saldığı bu hidroklorik asidin çevreye olan zararları yüksektir [3,4].

İki bölümden oluşan bildirinin birinci bölümünde; plastikler, genel özellikleri, çevresel etkileri ve geridönüşüm yöntemleri verilmiş olup, bildirinin bu bölümünde ise; PVC ve PET atıklarının kolon fotasyonu ile seçimli olarak ayrılmasında, laboratuvar ve pilot ölçekli deneylerle flotasyon parametreleri incelenerek, koşulların optimizasyonuna ilişkin sonuçlar tartışılmaktadır.

\section{GENEL BİLGILER}

Plastikler, yüksek molekül ağırlıklı organik moleküllerden ya da polimerlerden oluşmaktadır. Organik moleküller ve polimerler, birbirine kimyasal olarak bağlı birimlerin yinelenmesiyle ortaya çıkan zincir yapılardır. Bütün plastikler polimerizasyon ürünüdür. Plastik yapımının ön 
işlemi bunların monomerlere çevrilmesidir. Etilen gazı en yaygın olarak kullanılan monomerlerden birisidir. Sıcaklık, basınç ve birçok kimyasalın etkisiyle plastik üretiminin ikinci evresi başlamaktadır. Buna polimerizasyon denmektedir. Monomerler, zincir oluşturacak biçimde birbirine bağlanmakta ve rezinleri oluşturmaktadır. Etilen Polietilen'e, Propilen Polipropilen'e, Stiren Polistiren'e dönüşmekte, böylece, polimer veya plastikler meydana gelmektedir. Plastikler; 1sitıldığında erimeyen plastikler (termoset) ve 1sıltıldığında eriyebilen plastikler (termoplastik) olmak üzere iki gruba ayrılmaktadırlar [5-7].

Termoset Plastikler:Termoset terimi, hem oda sıcaklığında hem de daha yüksek sıcaklıkta çapraz bağlı yapıya dönüşebilen anlamına gelmektedir. Termoset plastiklerde polimer zincirleri arasında çapraz bağlar olması sebebiyle bu malzemeler her sıcaklıkta katı olarak bulunurlar.

Termoplastikler: Plastiklerin bir alt grubu olarak sinıflandırılabilen termoplastikler 1sıtıldığında eriyebilen düz ya da dallanmış polimerlerdir. Çapraz bağların olmaması nedeniyle isıtıldığında polimer zincirleri arasındaki görece zayıf kuvvetler ortadan kalkar ve bu zincirlerin birbirleri üzerinden kolaylıkla kaymasıyla malzeme akışkan bir hal alır. Termoplastikler ise; Polietilen Teraftalat (PET); Polivinil Klorür (PVC); Akronitril Butadien Stiren (ABS); Polikarbonat (PC); Polietilen (PE); Polipropilen (PP); Polistiren (PS) ve Polimetil Metakrilat (PMMA) gibi farklı özelliklerde alt gruplara ayrılmaktadır.

\subsection{Plastiklerin Kullanım Alanları}

Günümüzde plastikler, ahşap, kağıt, metal, cam, pamuk, yün, ipek ve kauçuk gibi pek çok doğal ürünün yerini almış ve insan hayatının vazgeçilmez bir parçası haline gelmiştir. Plastiklerin çeşitli şekillerde işlenebilme özelliğinin yanında maliyet avantajları da teknolojik gelişmelerin çoğunda hayati öneme sahip olmalarını sağlamıştır. Elektrik ve elektronik sanayinde de plastiklerin kullanılmasının başlıca nedenleri; daha iyi tasarımlara imkân verebilmeleri, olağanüstü yalıtım özelliğine sahip olmaları, parçaların mümkün olan en küçük boyutta imal edilebilmesi, montaj kolaylığı ve uygun ve hafif bir depolama ortamı sağlamalarıdır [1].

\subsection{Plastik Atıklar ve Geri Dönüșümü}

Plastik, dünyanın en değerli doğal kaynağı, petrolden üretilir. Plastik genellikle ambalaj malzemesi olarak kullanılır ve çöpe gider. Diğer bir değişle çöp yığınlarının 1/3'ü paketleme malzemesinden kaynaklanır. Plastikler, sonsuza dek çöp olarak kalır, yani hiç bir zaman doğaya geri dönmez. Günümüzde geri kazanılmış plastikten çöp torbasının yanı sıra bahçe çitleri, çiçek saksıları gibi uzun ömürlü tüketim malzemeleri yapılır. Toplam plastik atıklar içerisinde en büyük pay $\% 40$ ile ambalaj atıklarıdır ve bunların büyük çoğunluğu evsel atıklar içerisinde bulunmaktadır. Bunun yanında plastikler, paketleme ve ambalaj miktarını azaltmaktadır. Yani $1 \mathrm{~kg}$ plastik malzemeyle $27 \mathrm{~kg}$ sıvı ambalajlamak mümkün iken aynı miktarda Sıv1 için $1,5 \mathrm{~kg}$ alüminyum, $4 \mathrm{~kg}$ çelik veya 13-14 kg kadar cam malzemeye ihtiyaç vardır. Bu da doğal kaynakların korunması, tasarruf edilmesi anlamına gelmektedir. Kâğıtla karşılaştırıldığında, plastik malzeme aynı işi görecek kağıt malzemeden çok daha az toplam üretim enerjisi gerektirir [8].

Genellikle plastik atıklar, tüketiciler tarafından kullanım sonrası veya endüstride üretimi esnasında oluşur. Ekonomik öneme sahip yaklaşık 50 tip plastik mevcuttur. Toplam plastik tüketiminin yaklaşık \%60'ını PE, PET, PP, PS ve PVC gibi geleneksel polimerler kapsar. Hem yaşadığımız çevreyi, hem dünyamızı ve enerji kaynaklarımızı korumak, hem de üstün özelliklerinden faydalanmaya devam etmek için plastik malzeme geri dönüşümünü sağlamak gerekli ve önemlidir. Plastiğin geri dönüşümü her geçen gün biraz daha artmaya başlamış ve \%30 hatta bazı plastiklerde \%60 dönüşüm sağlanmıştır [8].

Plastik atıkların değerlendirilmesi için gereken birkaç basamak vardır. Bunlardan ilki plastik atıkların toplanma işlemidir. Daha sonra da plastik atıkların ayırma işlemine geçilmektedir. Ayırma türlerinden ilki, farklı tür plastiklerin değişik 
yoğunluklara sahip olması özelliğinden yararlanılarak yüzdürme-batırma ile ayırma yöntemidir. İkinci yöntemi elle ayıklama, hidrosiklon ile ayırma, hava ile sınıflandırma, depolimerizasyon, seçimli çözündürme ve lazer taraması gibi değişik türdeki ayırma teknikleri oluşturur . Son yöntem ise, flotasyon ile ayırmadır. Gravite veya diğer yöntemlerle ayrlamayan ve çoğu doğal olarak hidrofobik (suyu sevmeyen) olan plastiklerin bazılarının yüzeyine adsorbe olan kimyasallar ile yüzey özellikleri değiştirilmekte ve hidrofilik (suyu seven) özellik kazandırılarak batması ve hidrofob olan diğer plastik türünün oluşturulan hava kabarcıklarına tutunarak yüzmesi ve seçimli olarak ayrılması sağlanır. Yüzey özellikleri dikkate alındığında, plastiklerin hidrofobiklik dereceleri sırası ile büyükten küçüğe doğru $\quad$ PS $>$ ABS $>$ PC $>$ PET $>$ PMMA $>$ PVC $>$ POM şeklinde sıralanır. $\mathrm{Bu}$ siralamaya göre, PET ve PVC'nin hidrofobiklik dereceleri birbirine oldukça yakındır. $\mathrm{Bu}$ nedenle de, flotasyon uygulamalarında plastikleştirici reaktifler kullanarak yüzey özelliklerinin değiştirilmesi gerekmektedir [9-12].

PET ve Geri Dönüşümü: Geri kazanılmış PET'lerden halı tabanları, uyku tulumları, yastık, yorgan, giysilerdeki yalıtım maddesi, oto parçaları, boya firçaları, cankurtaran yastıkları, torbalar, posta kutuları, piknik masaları, çitler, yürüyüş botları, çift bölmeli kovalar, lazer toner kartuşu ve kayışlar gibi malzemeler üretilmektedir. PET'ten oluşan tekrar doldurulabilir kapların kullanım alanı gittikçe genişlemiştir [5].

PVC ve Geri Dönüşümü: Yapılan araştırmalarda; PVC tüketim alanlarında geri dönüşümünün tüketimine oranlandığında yüzde birden daha düşük miktarlarda olduğunu belirlenmiştir. Bağımsız bir araştırmaya göre PVC atıklarının \%75-80'inin orta ve uzun vadede geri dönüşümün bir alternatif bile olamayacağı belirtilmiştir. $\mathrm{Bu}$ yüz binlerce ton PVC'nin yakın bir gelecekte büyüyen bir bertaraf problemi yaratacağı anlamına gelmektedir.

PVC'nin geri dönüştürme işleminde başlica problem, ham PVC'nin yüksek oranlarda klor içermesi (polimer ağırlığının \%56'sı) ve istenilen materyal kalitesinin elde edilebilmesi için polimere eklenilen çok fazla tehlikeli olan katk1 maddeleridir. Katkı maddelerinin ağırlığı PVC ürün ağırlığının \%60’ını oluşturabilmektedir. Tüm plastikler içinde PVC en çok katkı maddesi içeren plastik türüdür. Sonuç olarak, PVC'nin diğer plastiklerden ayrıştırılması ve mekanik geri dönüştürme işleminden önce türlerine ayrılması gerekmektedir. $\mathrm{Bu}$ nedenle PET şişe geri dönüşümü yapanlar PVC şişelerinin karışımlarını kirletmediğinden emin olmalıdırlar [7].

\subsection{PET ve PVC Ayırımı ile İlgili Flotasyon Çalışmaları}

$\mathrm{Bu}$ başlık altında özellikle yüksek oranlarda kullanım alanları olan PET ve PVC'nin geri dönüşümünde flotasyon bazlı yapılmış çalışmalardan özetler derlenmiştir.

1999 yılında Drelich ve arkadaşlarının yapmış olduğu araştırmaya göre sodyum hidroksitin, güçlü alkali çözeltilerinin PET'in hidrofobik özelliğini yok ederek PVC'nin PET'ten ayrılmasina imkân sağladığı görülmüştür. Reaktif olarak $15-30 \mathrm{mg} / \mathrm{L}$ Rhodasurf 91-6 C9-11 Etoksilat alkol kullanılmıştır. $\quad 15-30$ dakika $75^{\circ} \mathrm{C}$ 'de alkali muamelesi sayesinde PVC, PET'ten ayrılmaktadır. $\mathrm{Bu}$ araştırmada sodyum hidroksitin PET'i hidrofilik yaparken, PVC'nin hidrofobik özelliğini çok etkilemediği görülmektedir. PET ve PVC karışımına plastikleştirici eklendiğinde yüksek sıcaklıkta PVC parçacıklarının hidrofobikliğini yüksek oranda artırdığı, PET parçacıklarını ise çok az etkilediği görülmüştür. Plastikleştirici olarak Diisodil Ftalat kullanılmıştır. Alkali ile 30 dakika muameleden sonra PVC ve PET'lerin her ikisi de 5-40 $\mathrm{mg} / \mathrm{L}$ sıcak plastikleştirici ile 30 dakika kıvamlandırılmış, ardından süzülüp kurutulmuştur. PET'in temas açısı sabit kalırken, PVC'ninki $15-18^{\circ} \mathrm{C}$ 'den $24-28^{\circ} \mathrm{C}$ 'ye çıkmıştır. Bu uygulamalar sırasında sıcaklığın önemli bir etken olduğu görülmüştür. Sicaklıkla birlikte plastikleştiricinin PVC üzerinde etkinliğinin arttığı tespit edilmiştir. Dietilen Glikol Dibenzoat kullanılarak yapılan deneylerde 3 dakikadan sonra yüksek verimle (\%95'den fazla) PET-PVC ayırımı yapılabilmiştir. Bu uygulama sayesinde \%93-95 
arasında PET elde edilip \%98-100 oranında PVC ayrılmıştır [13].

1999 yılında Shen ve arkadaşlarının yapmış olduğu çalışmada; hidrofilik yapan yüzey aktif maddelerin etki mekanizması araştırılmıştır. Seçimli hidrofilik yapmanın bir yolu kimyasal kıvamdır. $\mathrm{Bu}$ ise, reaktiflerin plastiklerin yüzeylerine adsorbe olması, kat1-sıv1 arası yüzey hidrofobikliğini azaltması esasına dayanmaktadır. Seçimli hidrofilik prosesi, farklı plastiklerin değişik sslanabilme şartları sayesinde gerçekleşmetedir. Polimerlerin adsorpsiyon mekanizması ile ilgili önerilen mekanizma şu şekildedir:

a) Plastiklerin polimer zincirlerinin lateral grupları polar olmayan karbon ve hidrojen içermektedir. $\mathrm{Bu}$ plastik yüzeyindeki moleküller ile bastırıcı etkideki moleküller arasındaki fiziksel etkileşimi açıklar. $\mathrm{Bu}$ reaksiyonlar itici Van-Der-Waals kuvvetleri ve hidrojen bağlar ile olmaktadır.

b) Bazı polimerler oksijen, azot, klor gibi atomlara sahip olan polar lateral gruplar içermektedir. $\mathrm{Bu}$ lateral gruplar bastırıcı moleküller ile Dipol-Dipol Van-Der-Waals ve Lewis asit-baz kuvvetleri ile etkileşim halindedir.

c) Plastik yüzey ve bastırıcı moleküller arasındaki kimyasal bağlanma çok nadirdir, çünkü plastikler düşük yüzey enerjilerine sahip, flotasyon prosesi boyunca kimyasal olarak neredeyse sabittir.

d) Minimum serbest yük taşıyanlar dahil olmadığı için elektrostatik etkileşimler pek az gerçekleşir [14].

2000 yılında yapılan bir çalışmaya göre, PET ve PVC'nin hidrofobik olduğu, ön muamele sayesinde birisini hidrofilik yapmanın mümkün olduğu belirlenmiştir. Reaktiflerin içerisinde en çok lignosülfonat, tannik asit kullanılmış ve plastiklerin üzerindeki bastırıcı etkisi araştırılmıştır. Saf suda yapılmış olan çalışmada reaktifin bastırıcı etkisi görülmemiştir. Reaktifle muamele neticesinde PVC'nin temas açısında değişim olmazken PET'in temas açısının $10^{\circ}$ düştüğü ve neticesinde hidrofilik olduğu gözlemlenmiştir [15].
2000 yılında yapılan başka bir araştırmada; flotasyonun en ucuz ve benzer yapıdaki tanelerin ayrılması için en uygun yöntem olduğu belirtilmiştir. Buna göre yüzey aktif madde olarak Kalsiyum Lignin Sülfonat, köpürtücü olarak MIBC kullanıldığında PVC'yi PET'ten ayırmak mümkün olmuştur. $\mathrm{Bu}$ reaktifler kullanıldığında kıvam için ideal zaman 60 dakika, en iyi ayırma boyutu, $-3,36+1,70 \mathrm{~mm}$ olarak saptanmıştır. Parça büyüklüğü arttıkça seçicilik artmakta fakat kazanım düşmektedir [12].

2001 yılında Shen ve arkadaşlarının yapmış olduğu çalışmalara göre, plastiklerin yüzebilirliği sadece kimyasal reaktiflerden değil yerçekimi faktöründen de etkilenmektedir. Buradan yola çıkılarak, parçacık büyüklüğünün kontrolü sayesinde plastik karışımlarının seçimli olarak ayrilabileceği gösterilmiştir [16].

2002 yılında Shen ve arkadaşlarının yapmış olduğu çalışmalara göre, POM, PVC, PET, PMMA, PC, PS ve ABS'nin yüzebilirliklerinin; Alkil Etoksilat noniyonik yüzey aktifleştirici madde varlığında azaldığı görülmüştür. Ancak her birisinin yüzebilirliği farklı azalmış, yüzebilirlikleri $\quad \mathrm{POM}<\mathrm{PVC}<\mathrm{PMMA}<\mathrm{PET}<\mathrm{PC}$ $<\mathrm{ABS}<\mathrm{PS}$ şeklinde sıralanmıştır. Alkil Etoksilat'ın bastırıcı olarak etki etmesinin nedeni, sıv1 yüzey gerilimini düşürmesidir. Düşük yoğunluklu daha fazla temas açısına sahip daha düşük şekil özelliklerine sahip olan plastiklerin daha yüksek yüzebilirliklere sahip oldukları saptanmıştır. Bu çalışmada; verimin \%99, içeriğinin \%97'den fazla olabildiği gözlemlenmiştir. [9]. 2003 yılında Pascoe ve O'Connell'ın yapmış olduğu çalışmalara göre, yakma yöntemi plastik yüzeyine oksijenli fonksiyon grubu ilavesinde sonuç vermiştir. PVC'nin yumuşama noktasının üzerinde $\left(75^{\circ} \mathrm{C}\right)$ hızlı bir şekilde hidrofobik yüzeye sahip olduğu ancak PET'in ise hidrofilik kaldığı gözlenmiştir. Temas açısının yumuşama noktasından sonra $\mathrm{pH}$ ile etkili bir şekilde değiştiği saptanmıştır. PVC'nin sıfir yük noktası $\mathrm{pH} 4$ 'de elde edilmiştir. PET ve PVC'nin pH 4 ile 7 arasında köpürtücü kullanmadan yüzebildiği görülmüştür [17]. 2006 yılında Takoungsakdakun ve Pongstabodee'in yapmış olduğu çalışmalara göre, POM, PET ve PVC karışımından ıslatıcı madde olarak $500 \mathrm{mg} / \mathrm{L}$ 
kalsiyum lignosülfonat, $\mathrm{pH} 7$ ve $220 \mathrm{~mL} /$ dak hava hızı şartlarında ayrılmıştır. PET'in PVC'den ayrılması için $\mathrm{pH} 5.8$ ve $180 \mathrm{ml} /$ dak hava hızı şartlarında $500 \mathrm{mg} / \mathrm{L}$ Kalsiyum Lignosülfonat ve $\% 0,01$ oranında $\mathrm{Al}_{2}\left(\mathrm{SO}_{4}\right)_{3}$ ilavesiyle flotasyon gerçekleştirilmiştir. PET'in sıfır yük noktası pH 6,5; PVC'nin ise pH 5,8'dir. Sifır yük noktası şartları sağlandığında PVC PET'ten ayrılmaktadır [18]. 2007 y1lında İstanbul Teknik Üniversitesi Maden Mühendisliği Bölümü'nde yapılan çalışmalarda; PET'in PVC'den seçimli olarak ayrılması için Dietilen Glikol Dibenzoat kullanılarak gerçekleştirilen flotasyon deneyleri sonucunda optimum koşullar $\mathrm{pH} 4,1000 \mathrm{~g} / \mathrm{t}$ Dietilen Glikol Dibenzoat, 5 dakika kıvam süresi ve 3 dakika köpük alma süresi olarak belirlenmiştir. İki kademede gerçekleştirilen kolon flotasyonu deneyi sonunda, $\% 42,1$ oranında $\% 100$ saflıkta PET konsantresi, \%84,3 PET kazanma verimiyle elde edilmiştir [19]. 2009'da ki diğer bir çalışmada ise; $50 \mathrm{~L} / \mathrm{sa}$ hava, $\mathrm{pH} 8$ 'de ve $25 \mathrm{~g} / \mathrm{t}$ Lignin Alkali kullanılarak yapılan deneyler sonucunda, PET, \%99,93 içerik ve \%99,8 verim ile geri kazanılmıştır [20].

\subsection{Kolon Flotasyonu}

Flotasyon kolonlarını diğer flotasyon makinalarından ayıran en önemli özellikler; mekanik karıştırıcısının bulunmaması, kabarcık üretecinin varlığı ve yıkama suyunun kullanımı olarak siralanmaktadır [21]. Sayılan bu farklılıkların kolona sağladığı en önemli avantajlar ise, üretilen konsantrenin kalitesi (tenörü) yüksektir. Düşük enerji tüketimi sağlar. Otomatik kontrol imkanı yüksektir. Kapladığı yüzey alanı düşüktür. Verilen hava debisi yüksek olduğundan dolayı işlem kapasitesi yüksektir. Yapımı ve dizaynı kolaydır. Yatırım ve bakım masrafları daha düşüktür. Zenginleştirilecek cevherin boyut aralığ oldukça yüksektir $(10 \mu \mathrm{m}-2,3 \mu \mathrm{mm})$. Klasik flotasyon hücrelerine göre avantajlarının yanında kolonun dezavantajları ise şunlardır; Kolonun bulunduğu yerin tavan yüksekliği oldukça fazla olmalıdır (13-14 metre) ve fazladan yıkama suyuna ihtiyaç duyulmaktadır. Laboratuvar tipi kolon flotasyonu ünitesinin klasik flotasyon ünitesi ile mukayeseli bir resmi Şekil 1'de verilmektedir.

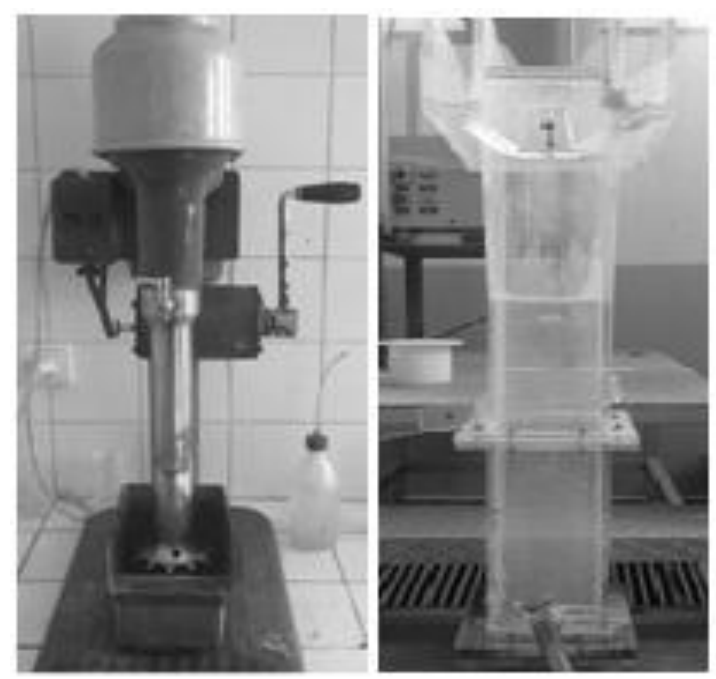

Şekil 1. Laboratuvar tipi klasik flotasyon (solda) ve kolon flotasyon hücresi (sağda)

Flotasyon kolonları genelde çalışma ilkeleri aynı olmakla birlikte; klasik ve modifiye flotasyon kolonu olmak üzere ikiye ayrılırlar; Bu iki flotasyon kolonu arasındaki farklılıklar şu şekilde siralanabilir;

- Modifiye kolonda köpük zonu yoktur,

- Klasik kolonda artık çıkışının debisi (Qa) ile besleme debisi (Qb) arasındaki fark $($ Bias $=$ Qa-Qb) pozitiftir. Diğerinde ise negatiftir,

- Klasik kolonda yıkama suyunu ilave etmek gerekir. Diğerinde ise zorunlu değildir,

- Modifiye kolon iri tanelerin zenginleştirilmesinde kullanılır.

Kolon dışında koşullandırılmış zenginleştirilecek mineral yaklaşık \%5-30 katı oranı ile besleme noktasından kolona beslenmektedir. Beslenen taneler, gravite etkisiyle zenginleştirme zonunda düşerken, kabarcık üreteci tarafindan üretilen hava kabarcıkları yükselmeye başlar. Hava kabarcıklarıyla karşılaşan hidrofob parçacıklar arasında flotasyonun mikro olayları (çarpışma, yapışma vs.) gerçekleştikten sonra tane-kabarcık agregaları oluşur. Oluşan agregalar köpük zonunu geçer ve kolonun üst kısmindan kolonu terk ederken, yüzmeyen parçacıklar ise, kolonun 
tabanına doğru düșer ve kolonu terk eder. Yüzmeyen tanelerin konsantre içinde sürüklenmesini (hidrolik veya sıkışma yoluyla) önlemek için kolonun üst kısmından yıkama suyu ilave edilir. Sonuç olarak yüzmeyen parçacıklar ve bir kısım hidrofob parçacıklar temizleme zonundan zenginleştirme zonuna geri dönerler. Yıkama suyunun diğer bir etkisi de, köpük zonunun varlığını ve seviyesini ayarlamaktır. İlave edilen yıkama suyunun bir kısmı zenginleştirme zonuna geçer, geriye kalan kısmı köpük zonundan kolonu terk eder $[22,23]$.

\subsubsection{Flotasyon Kolonunda Oluşan Zonların Tanımı}

Klasik flotasyon kolonunda, Şekil 2'de görüldüğü gibi 2 temel zon tanımlanır. Bu zonlar; kolonun alt kısmını oluşturan ve zenginleştirme olayının gerçekleștiği zenginleștirme zonu ve üst kısmında hava kabarcıklarının yoğun olarak bulunduğu köpük zonu olarak adlandırılır. Bu iki zon arasında farklı hava kabarcığı konsantrasyonu sebebiyle belirgin bir ara yüzey gözlenebilmektedir. Kolonda flotasyon prosesinin başarısı için bu özelliklerin iyi bilinmesi gerekir [23].

Zenginleştirme Zonu: Kolonun alt kısmını oluşturan ve flotasyonun mikro olaylarının (karşılaşma, çarpışma, yapışma, kopmama ve parçacık-kabarcık yükselmesi) gerçekleştiği zondur. Bu bölgede gaz tutunum yüzdesi \%10-20 arasındadır [24]. Pülp beslemesi, bu zonun hemen üstünden yapılır. Besleme içindeki mineral parçacıkları pülp ile inerken kolon dibinde hava üreteci tarafından üretilen ve yükselen hava kabarcıkları ile karşılaşır. [22]. Flotasyonun fiziksel mikro olayları hidrofob parçacıklar ile kabarcıklar arasında gerçekleştikten sonra kabarcık-parçacık agregaları köpük zonuna doğru yükselirler. Çoğunlukta olan hidrofil taneler bu zonun alt kısmındaki artık çıkışından kolonu terk ederler.

Hava üreteçleri genelde poroz paslanmaz çelikten yapılır. Kauçuk veya filtre bezinden imal edilmiş hava üreteçleri de alternatif olarak kullanılabilir. Köpürtücü ilave edilen sulu ortamda $2 \mathrm{~mm}$ veya daha küçük çaplı hava kabarcığı veren hava kabarcığı üreteçleri tercih edilir [25]. Kolona verilen gaz debisi $(\mathrm{Qg})$ ile kabarcık üreteci yüzey alanı (As) arasında bir oranlama düşünüldüğünde, gaz debisi arttıkça, kabarcık üreteci birim yüzey alana düşen hacimsel gaz miktarı ve kabarcık çapı da artar ve sonuç olarak belirli bir noktadan sonra verimin düştüğü görülür. Genelde endüstriyel ölçekte 4-40 delik/ $\mathrm{cm}^{2}$ hava üreteçleri kullanılır. Qg/As oranı yaklaşık olarak 2-5,5 cm/sn arasındadir [26].

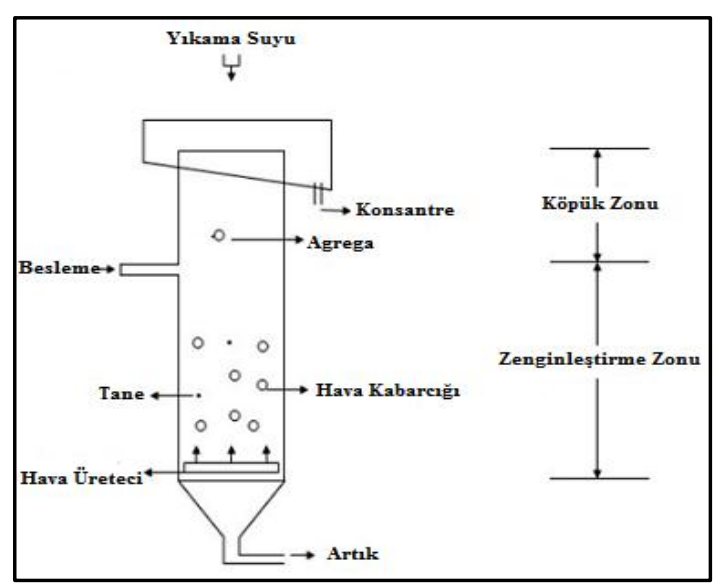

Şekil 2. Flotasyon kolonu zonları

Köpük Zonu: \%60-70 civarında gaz tutunumu olan ve konsantrenin yıkama suyu ilavesi ile y1kandığ1 bölgedir. Gaz tutunumunun \%74'ten fazla olması, istenmeyen kabarcık birleşimine neden olmaktadır. Bu zonun yüksekliği arttıkça, konsantrenin tenörü artar fakat verimi düşer. Köpük zonunun toplam verim üzerine etkisi negatiftir. Köpük zonunun varlığı Bias değerine bağlıdır. Bias değeri negatif ise köpük oluşmaz $[23,26,27]$.

\section{MALZEME VE YÖNTEM}

$\mathrm{Bu}$ araştırma kapsamında; PET ve PVC'nin seçimli olarak ayrılmasına yönelik pilot ölçekli kolon flotasyonu ünitesi kullanılarak, flotasyon parametrelerinin belirlenmesi üzerine çalışmalar yapılmıştır. Bu konu ile ilgili literatür bilgileri de göz önünde bulundurularak, PET ve PVC'nin 
seçimli olarak ayrılmasında etkili olan kolon ve flotasyon parametreleri detaylı olarak incelenmiş, flotasyon koşullarının optimizasyonu gerçekleştirilmiştir. Deneysel çalışmalarda, öncelikle laboratuar ölçekli kolon flotasyonu ünitesi kullanılarak flotasyon parametrelerine ilişkin ön veriler üretilmiş, daha sonra bu veriler baz alınarak pilot ölçekli kolon ünitesinde deney optimizasyonu gerçekleştirilmiştir [22].

Deneysel çalışmalar Plaş A.Ş.'den temin edilen kullanılmış PET şişe ve pencere profili olarak kullanılan PVC numuneleri üzerinde gerçekleştirilmiştir. PET ve PVC'ler Net Plasmak LTD NPS 400 marka plastik kırma ünitesinde 6 $\mathrm{mm}$ altına kırılmış ve kolon flotasyonuna uygun boyutlar alınarak deneyler gerçekleştirilmiştir. Deneylerde, daha önceki çalışmalardan elde edilen verilere göre $-3,35+2,0 \mathrm{~mm}$ boyut aralığında çalışmalar yapılmış, bunun yanı sıra PET ve PVC'den kazanım oranlarını arttırmak amaciyla farklı boyut gruplarında da $(-3,35+1,19 \mathrm{~mm}$ ve $-2,0+1,19 \mathrm{~mm})$ pilot ölçekli deneyler sürdürülmüştür.

Laboratuar ölçekli deneylerde kenar uzunluğu 5 $\mathrm{cm}$, yüksekliği $25 \mathrm{~cm}$ olan kare kesitli kolon flotasyonu ünitesi kullanılmıştır. Laboratuvar ölçekli kolon ünitesinden alınan verilerin teyidi/karşılaştırması için; 13×13 cm kare kesitli ve her bir ünitesi $31 \mathrm{~cm}$ yüksekliğinde, ünitelerin birbirine bağlanması ile kolon yüksekliğinin arttırılabildiği, hava basıncının ve yıkama suyu ayarlarının otomatik kumanda ile yapılabildiği pilot ölçekli kolon flotasyonu ünitesi kullanılmıştır.

Deneylerde, plastikleştirici olarak Diethylene Glycol Dibenzoate ve Lignin Alkali, köpürtücü reaktif olarak Metil İzobütil Karbinol (MIBC), pH ayarlayıcı olarak da $\mathrm{NaOH}$ kullanılmıştır. Tüm deneylerde malzemeler kolona beslendikten sonra, plastikleştirici ilave edilerek kıvamlandırma için belirli bir süre verilmiş, ardından da MIBC katılarak uygun sürelerde köpük alınmıştır. Malzemeler kurutulduktan sonra, alınan ürünlerde PET ve PVC sayım yöntemi ile sonuçlar değerlendirilmiştir.

\section{DENEYSEL ÇALIŞMALAR}

\subsection{Malzeme Tanımlama Çalışmalar}

PET ve PVC numunelerinin kırma sonrası elde edilen boyut dağılımları Çizelge 1'de verilmektedir. $6 \mathrm{~mm}$ altına kırılmış PVC ve PET numunelerinin $d_{80}$ ve $d_{50}$ boyutlarının sirasiyla $4,2 \mathrm{~mm} ; 2,8 \mathrm{~mm}$ ve $4,7 \mathrm{~mm}, 3,35 \mathrm{~mm}$ olduğu belirlenmiştir.

\subsection{PET ve PVC'nin Yüzey Özelliklerinin Belirlenmesi}

Deneylerde kullanılacak olan PET ve PVC'lerin yüzey özelliklerinin belirlenmesi ve yüzey yüklerinin tespit edilmesi amacı ile zeta potansiyel ölçümleri gerçekleştirilmiştir.

Öncelikli olarak, PET ve PVC tanelerinin suya iyon verip vermediğini kontrol etmek amacı ile $\% 1$ 'lik pülpte katı oranı olacak şekilde, PET ve PVC numuneleri bir karıştırıcı üzerinde sürekli karıştırılarak, belirli aralıklarla karışımın pH değeri ölçülmüştür. Toplam 360 dakika boyunca yapılan ölçümlerden, pH'nın zamana göre değişim karakteristiği Şekil 3'de verilmiştir. PET ve PVC'nin bulunduğu ortamlarda başlangıç $\mathrm{pH}$ değerleri çok küçük değişiklikler göstermekle birlikte $(6,0-6,6), 1$. saat civarında denge $\mathrm{pH}$ değeri olan 6,9 değerine ulaşmakta, ölçümlerin tamamlandığı 6. saat sonunda da bu denge $\mathrm{pH}$ değerlerinin sabit kaldığı belirlenmiştir.

Diğer yandan; PET ve PVC numunelerine ait yüzey yüklerinin belirlenmesi amaciyla saf su ortaminda ve Lignin Alkali'nin bulunduğu koşullarda pH'ya bağlı olarak zeta potansiyel ölçümleri yapılmıştır.

Ölçümlerden elde edilen veriler Şekil 4, 5 ve 6'da verilmiştir. Plastikleştirici olarak Lignin Alkali'nin kullanıldığı durumlarda ise plastikleştirici konsantrasyonunun artmasına bağlı olarak PET ve PVC yüzeylerinin negatif yüklerinin arttığı görülmektedir. 
Çizelge $1.6 \mathrm{~mm}$ altına kırılmış PVC ve PET numunelerinin boyut dağılımı

\begin{tabular}{|c|c|c|c|c|c|c|}
\hline Boyut Aralığ $(\mathrm{mm})$ & \multicolumn{3}{|c|}{ PVC } & \multicolumn{3}{c|}{ PET } \\
\cline { 2 - 7 } & $\begin{array}{c}\text { Miktar } \\
(\%)\end{array}$ & $\begin{array}{c}\sum \text { EÜ } \\
(\%)\end{array}$ & $\begin{array}{c}\sum \text { EA } \\
(\%)\end{array}$ & $\begin{array}{c}\text { Miktar } \\
(\%)\end{array}$ & $\begin{array}{c}\sum \text { EÜ } \\
(\%)\end{array}$ & $\begin{array}{c}\sum \text { EA } \\
(\%)\end{array}$ \\
\hline$-6+3,35$ & 25,5 & 25,5 & 100,0 & 50,7 & 50,7 & 100,0 \\
\hline$-3,35+2,0$ & 63,3 & 88,8 & 74,5 & 30,7 & 81,4 & 49,3 \\
\hline$-2,0+1,19$ & 10,3 & 99,1 & 11,2 & 13,7 & 95,1 & 18,6 \\
\hline$-1,19+0,5$ & 0,7 & 99,8 & 0,9 & 3,6 & 98,7 & 4,9 \\
\hline$-0,5$ & 0,2 & 100,0 & 0,2 & 1,3 & 100 & 1,3 \\
\hline Toplam & $\mathbf{1 0 0 , 0}$ & & & $\mathbf{1 0 0 , 0}$ & & \\
\hline
\end{tabular}

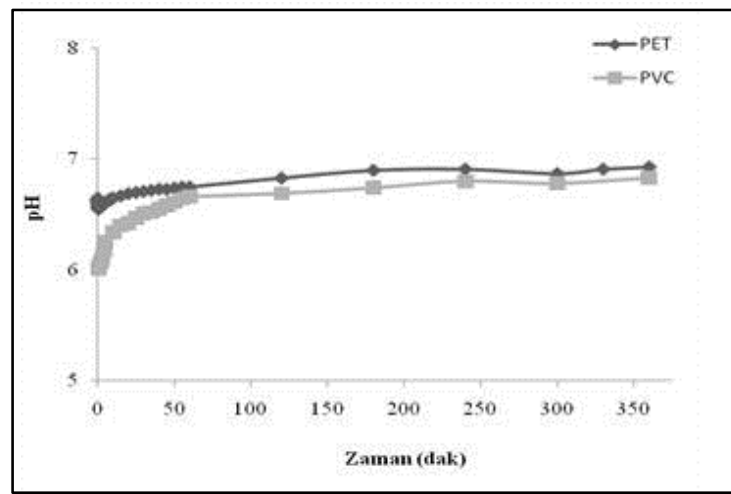

Şekil 3. PET ve PVC'nin zamana göre $\mathrm{pH}$ değişimi

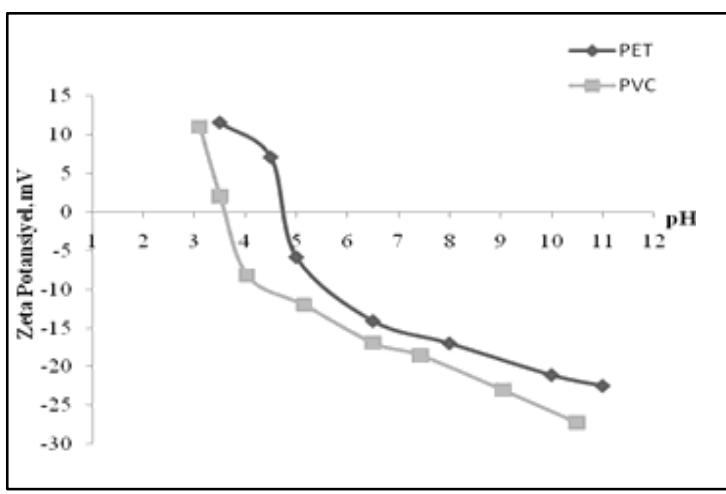

Şekil 4. PET ve PVC'nin saf suda zeta potansiyel ölçümleri

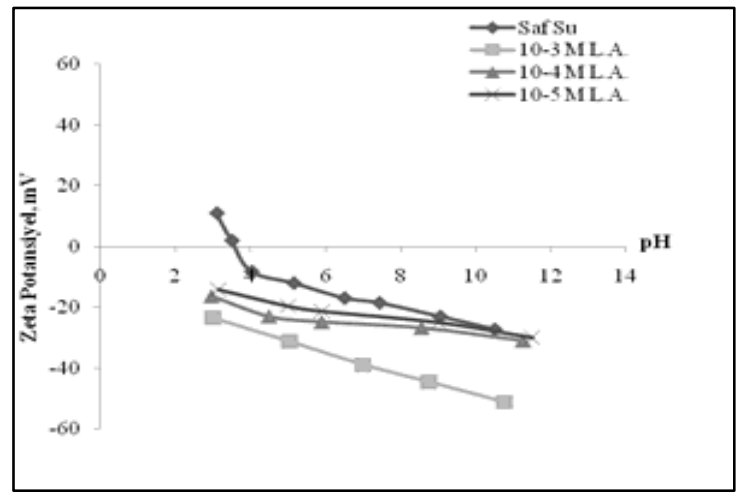

Şekil 5. PVC'nin lignin alkali ortamında zeta potansiyel ölçümleri

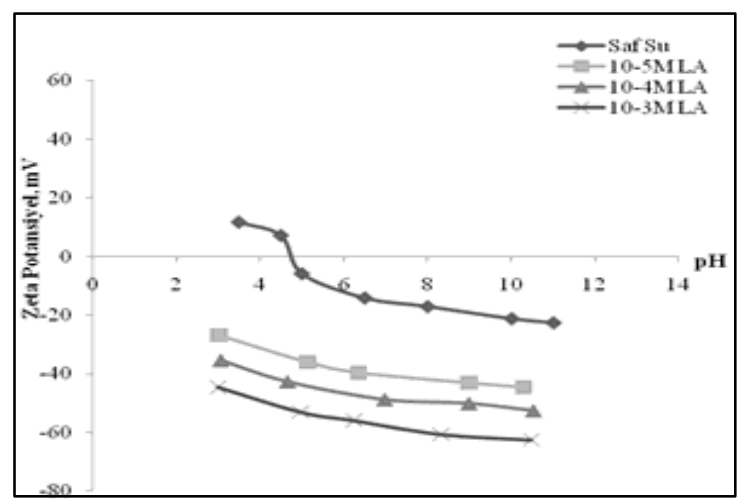

Şekil 6. PET'in lignin alkali ortamında zeta potansiyel ölçümleri 


\subsection{Laboratuvar Ölçekli Kolon Flotasyonu Deneyleri}

Pilot ölçekte gerçekleştirilecek deneylere veri sağlamak üzere, laboratuar ölçekli kolon flotasyonunda çeşitli parametrelerin incelendiği deneyler yapılmıştır. Bu deneylerde daha önceden yapılmış çalışmalarda optimize edilmiş olan kolon boyutu, pülpte katı oranı, yıkama suyu, reaktif ve köpürtücü cinsi sabit tutulmuş, 1/1 oranında karıştııılmış PVC/PET üzerinde tane boyutu, ortam $\mathrm{pH}$ 's1, reaktif ve köpürtücü konsantrasyonu ve pülp sıcaklığı değişken parametreler olarak incelenmiştir.
Plastikleş̧tirici Reaktif Konsantrasyonun Değişimi: Deneylerin başlangıcında, daha önceden yapılmış çalışmalar da dikkate alınarak, plastikleştirici olarak Lignin Alkali ve Diethylene Glycol Dibenzoate (DIB) reaktifleri ile bir seri ön deneyler yapılmış, DIB'nin deneylerde kullanılan PET ve PVC için hiçbir etkili sonuç vermemesi nedeni ile sadece Lignin Alkali kullanılarak sistematik deneyler yapılmıştır. Aşağıda verilen sabit koşullarda farklı konsantrasyonlarda Lignin Alkali kullanılarak yapılan deneylerden elde edilen sonuçlar Çizelge 2'de verilmiştir. Reaktif konsantrasyonunun değişimine bağlı olarak PET ve PVC içerik ve kazanma verimlerine ilişkin değerlendirmeler ise Şekil 7 ve 8'de verilmektedir.

\begin{tabular}{|c|c|c|c|c|}
\hline \multicolumn{5}{|c|}{ Numune boyutu: $(-3,35+2,0 \mathrm{~mm})$} \\
\hline $\mathrm{pH}$ & Hava Miktarı & MIBC & Kıvam Süresi & Köpük Alma Süresi \\
\hline 8 & $50 \mathrm{~L} / \mathrm{sa}$ & $1000 \mathrm{~g} / \mathrm{t}$ & 5 dakika & 3 dakika \\
\hline
\end{tabular}

Çizelge 2. PET ve PVC ayırımında reaktif konsantrasyonunun etkisi

\begin{tabular}{|c|c|c|c|c|c|c|}
\hline \multirow{2}{*}{$\begin{array}{c}\text { Reaktif Miktar1, } \\
\text { g/t }\end{array}$} & \multirow{2}{*}{ Ürünler } & \multirow{2}{*}{ Miktar, \% } & \multicolumn{2}{|c|}{ İçerik, \% } & \multicolumn{2}{|c|}{ Verim, \% } \\
\cline { 4 - 7 } & & & & & & \\
\hline \multirow{4}{*}{12,5} & Yüzen & 90,1 & 54,81 & 45,19 & 98,7 & 81,4 \\
\cline { 2 - 7 } & Batan & 9,9 & 6,38 & 93,62 & 1,3 & 18,6 \\
\cline { 2 - 7 } & Toplam & $\mathbf{1 0 0 , 0}$ & $\mathbf{5 0 , 0 0}$ & $\mathbf{5 0 , 0 0}$ & $\mathbf{1 0 0 , 0}$ & $\mathbf{1 0 0 , 0}$ \\
\hline \multirow{3}{*}{25} & Yüzen & 55,3 & 81,93 & 18,07 & 90,7 & 20,0 \\
\cline { 2 - 7 } & Batan & 44,7 & 10,45 & 89,55 & 9,3 & 80,0 \\
\cline { 2 - 7 } & Toplam & $\mathbf{1 0 0 , 0}$ & $\mathbf{5 0 , 0 0}$ & $\mathbf{5 0 , 0 0}$ & $\mathbf{1 0 0}$ & $\mathbf{1 0 0}$ \\
\hline \multirow{3}{*}{50} & Yüzen & 12,4 & 71,43 & 28,57 & 17,7 & 7,1 \\
\cline { 2 - 7 } & Batan & 87,6 & 46,98 & 53,02 & 82,3 & 92,9 \\
\cline { 2 - 7 } & Toplam & $\mathbf{1 0 0 , 0}$ & $\mathbf{5 0 , 0 0}$ & $\mathbf{5 0 , 0 0}$ & $\mathbf{1 0 0 , 0}$ & $\mathbf{1 0 0 , 0}$ \\
\hline
\end{tabular}




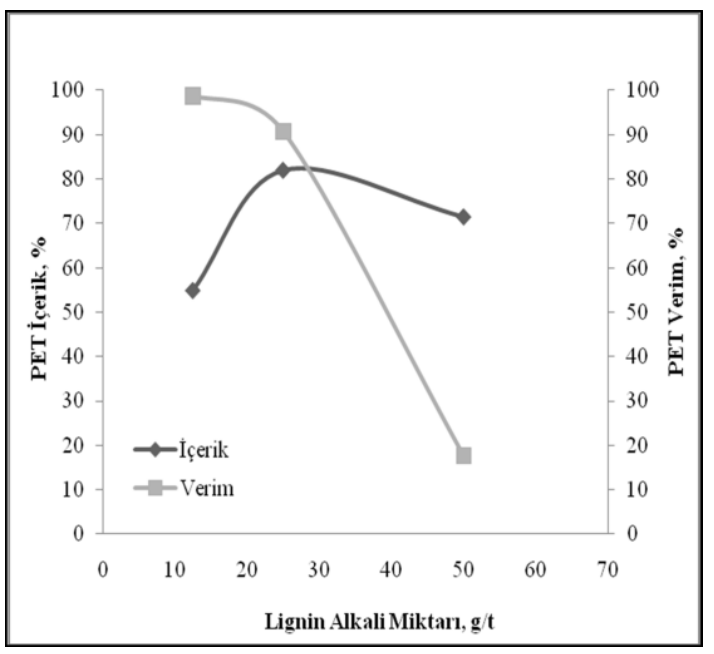

Şekil 7. Reaktif miktarının yüzen mazemedeki PET içerik ve verimine etkisi

Sonuçlar değerlendirildiğinde, gerek PET ve gerekse PVC açısından en uygun Lignin Alkali konsantrasyonunun, $25 \mathrm{~g} / \mathrm{t}$ mertebesinde olduğu görülmekte, bu konsantrasyonda ise yüzen malzemede \%81,9 PET içeriğinde bir ürünün, \%90,7 kazanma verimi ile elde edilebileceği görülmektedir.

pH Değişiminin Incelenmesi: Lignin Alkali ile yapılan PET-PVC flotasyonunda, $\mathrm{pH}$ değişiminin etkisinin incelendiği deneylerde, aşağıda verilen sabit koşullarda gerçekleştirilmiştir. Farklı pH değerlerinde elde edilen sonuçlar Çizelge 3'te gösterilmiştir. PH değişimine bağlı olarak PET ve PVC içerik ve kazanma verimlerine ilişkin değerlendirmeler ise Şekil 9 ve 10 'da verilmektedir.

Çizelge 3 'te görüldüğü gibi, yüzen ürünlerin PET içeriği $\mathrm{pH}$ artışına bağlı olarak artmaktadır, ancak PET kazanma verimi $\mathrm{pH}$ 8'de en iyi değere ulaşmaktadır. pH'nın düşük tutulması, flotasyon sonuçlarını doğal pH'da alınan değerlere göre negatif yönde etkilemektedir (Şekil 9). Diğer yandan batan malzemede PVC verimi dikkate alındığında ise uygun $\mathrm{pH}$ değerinin 10 olduğu görülmektedir (Şekil 10).

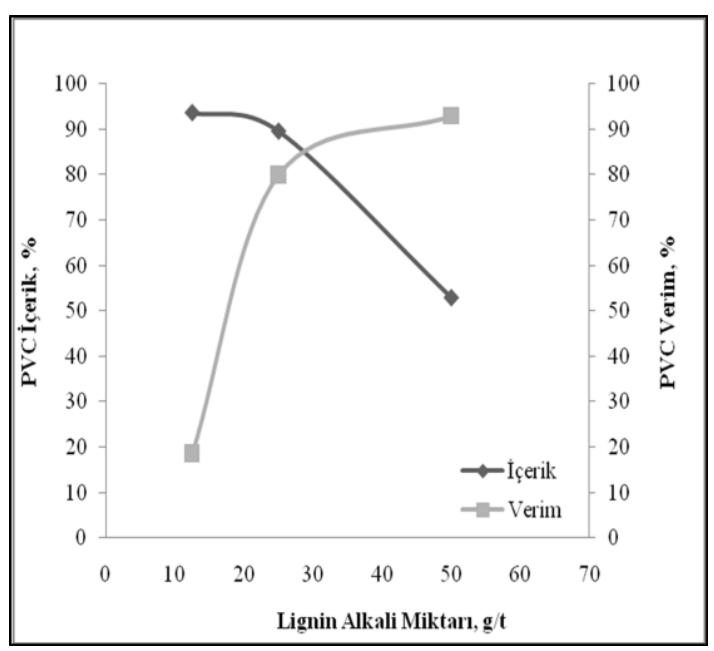

Şekil 8. Reaktif miktarının batan malzemedeki PVC İçerik ve verimine etkisi

Tane Boyutu Değişiminin Flotasyona Etkisi: Literatür verilerine göre; akademik çalışmalarda, plastik flotasyonunun gerçekleştirildiği optimum boyut aralığ $1(-3,35+2,0 \mathrm{~mm})$ olarak verilmektedir. Plastik atıklardan geri kazanım amacına yönelik geliştirilmesi ön görülen kazanım sistemlerinde, olanaklı olduğunca atıklardan fazla miktarda bölümlerin kazanılması düşünülmelidir. Bu nedenle; daha önceden yapılmış çalışmalarda uygulanmış boyut aralığ $(-3,35+2,0 \mathrm{~mm})$ dişında farklı boyut gruplarında da flotasyon yapılarak daha fazla ürünün kazanımı olanakları incelenmiştir. $\mathrm{Bu}$ amaçla, aşağıda verilen sabit koşullarda 3 farklı boyut grubunda kolon flotasyonu deneyleri yapılmıştır. Elde edilen sonuçlar Çizelge 4'de verilmiştir. Tane boyutu değişimine bağlı olarak PET ve PVC içerik ve kazanma verimlerine ilişkin değerlendirmeler ise Şekil 11 ve 12'de verilmektedir. Grafikler incelendiğinde, gerek PET ve gerekse PVC içerik ve verimleri açısından uygun tane boyutu, literatür verilerine de uygun olarak $-3,35+2,0 \mathrm{~mm}$ boyut aralığında elde edilmektedir. Ancak, alt boyutun bir miktar daha düşürülmesi sonucu da $(-3,35+1,19 \mathrm{~mm})$ elde edilen değerlerin bir önceki boyut grubuna yakın olduğu değerlendirmesi yapılmaktadır. 


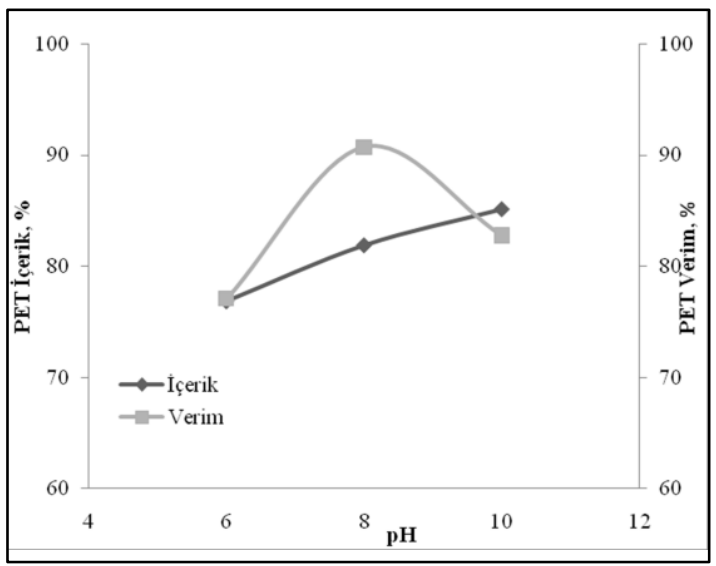

Şekil 9. pH'nın PET içerik ve verimine etkisi

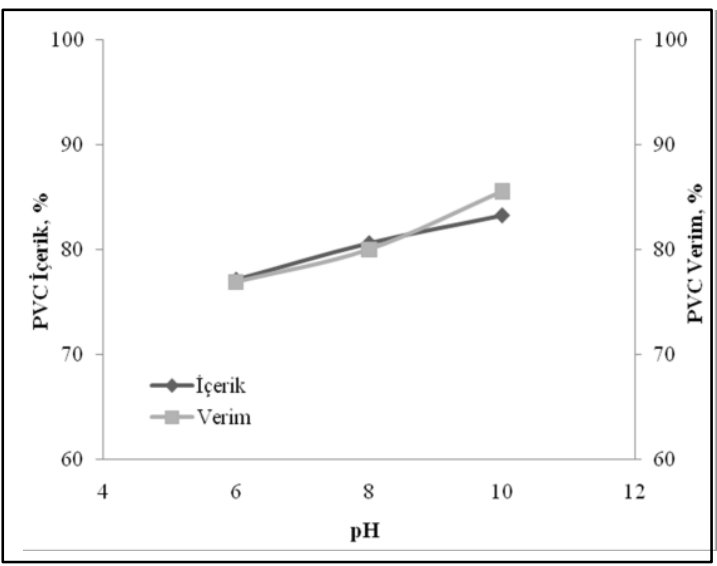

Şekil 10. pH'nın PVC içerik ve verimine etkisi

\begin{tabular}{|c|c|c|c|c|}
\hline \multicolumn{5}{|c|}{ Numune boyutu: $(-3,35+2,0 \mathrm{~mm})$} \\
\hline Lignin Alkali Kons. & Hava Miktarı & MIBC & Kıvam Süresi & Köpük Alma Süresi \\
\hline $25 \mathrm{~g} / \mathrm{t}$ & $50 \mathrm{~L} / \mathrm{sa}$ & $1000 \mathrm{~g} / \mathrm{t}$ & 5 dakika & 3 dakika \\
\hline
\end{tabular}

Çizelge 3. PET ve PVC flotasyonunda pH'nın etkisi

\begin{tabular}{|c|c|c|c|c|c|c|}
\hline \multirow[t]{2}{*}{$\mathrm{pH}$} & \multirow[t]{2}{*}{ Ürünler } & \multirow[t]{2}{*}{ Miktar, \% } & \multicolumn{2}{|c|}{ İçerik, \% } & \multicolumn{2}{|c|}{ Verim, \% } \\
\hline & & & PET & PVC & PET & PVC \\
\hline \multirow{3}{*}{6} & Yüzen & 50,1 & 76,90 & 23,10 & 77,1 & 23,1 \\
\hline & Batan & 49,9 & 22,90 & 77,10 & 22,9 & 76,9 \\
\hline & Toplam & 100,0 & 50,00 & 50,00 & 100,0 & 100,0 \\
\hline \multirow{3}{*}{8} & Yüzen & 55,3 & 81,90 & 18,10 & 90,7 & 20,0 \\
\hline & Batan & 44,7 & 10,40 & 80,60 & 9,3 & 80,0 \\
\hline & Toplam & 100,0 & 50,00 & 50,00 & 100,0 & 100,0 \\
\hline \multirow{3}{*}{10} & Yüzen & 48,6 & 85,13 & 14,87 & 82,8 & 14,5 \\
\hline & Batan & 51,4 & 16,74 & 83,26 & 17,2 & 85,5 \\
\hline & Toplam & 100,0 & 50,00 & $\mathbf{5 0 , 0 0}$ & 100,0 & 100,0 \\
\hline
\end{tabular}




\begin{tabular}{|c|c|c|c|c|c|}
\hline $\mathrm{pH}$ & L.Alkali Kons. & Hava Miktarı & MIBC & Kıvam Süresi & Köpük Alma Süresi \\
\hline 8 & $25 \mathrm{~g} / \mathrm{t}$ & $50 \mathrm{~L} / \mathrm{sa}$ & $1000 \mathrm{~g} / \mathrm{t}$ & 5 dakika & 3 dakika \\
\hline
\end{tabular}

Çizelge 4. PET ve PVC foltasyonuna tane boyutunun etkisi

\begin{tabular}{|c|c|c|c|c|c|c|}
\hline \multirow{3}{*}{ Boyut, mm } & \multirow{2}{*}{ Ürünler } & \multirow{2}{*}{ Miktar, \% } & \multicolumn{2}{|c|}{ İçerik, \% } & \multicolumn{2}{|c|}{ Verim, \% } \\
\cline { 4 - 7 } & & & PET & PVC & PET & PVC \\
\hline \multirow{3}{*}{$-3,35+1,19$} & Yüzen & 62,4 & 70,00 & 30,00 & 87,3 & 37,5 \\
\cline { 3 - 7 } & Batan & 37,6 & 16,90 & 83,10 & 12,7 & 62,5 \\
\cline { 2 - 7 } & Toplam & $\mathbf{1 0 0 , 0}$ & $\mathbf{5 0 , 0 0}$ & $\mathbf{5 0 , 0 0}$ & $\mathbf{1 0 0 , 0}$ & $\mathbf{1 0 0 , 0}$ \\
\hline \multirow{3}{*}{$-2,0+1,19$} & Yüzen & 52,4 & 62,50 & 37,50 & 65,5 & 39,3 \\
\cline { 2 - 7 } & Batan & 47,6 & 36,30 & 63,70 & 34,5 & 60,7 \\
\cline { 2 - 7 } & Toplam & $\mathbf{1 0 0 , 0}$ & $\mathbf{5 0 , 0 0}$ & $\mathbf{5 0 , 0 0}$ & $\mathbf{1 0 0 , 0}$ & $\mathbf{1 0 0 , 0}$ \\
\hline \multirow{3}{*}{$-3,35+2,0$} & Yüzen & 55,3 & 81,93 & 18,07 & 90,7 & 20,0 \\
\cline { 2 - 7 } & Batan & 44,7 & 10,45 & 89,55 & 9,3 & 80,0 \\
\cline { 2 - 7 } & Toplam & $\mathbf{1 0 0 , 0}$ & $\mathbf{5 0 , 0 0}$ & $\mathbf{5 0 , 0 0}$ & $\mathbf{1 0 0 , 0}$ & $\mathbf{1 0 0 , 0}$ \\
\hline
\end{tabular}

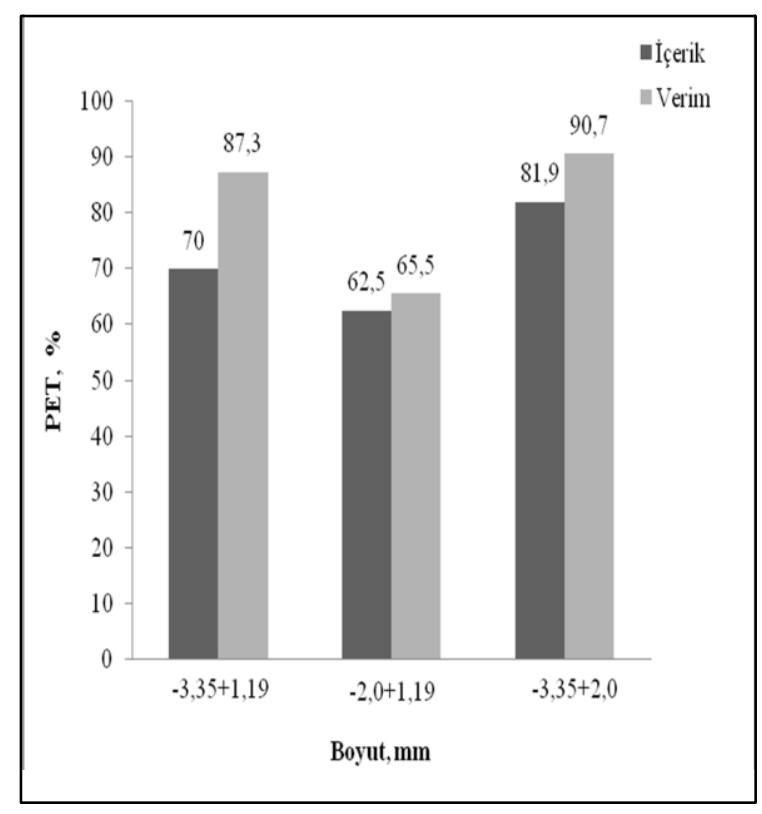

Şekil 11. Tane boyutunun PET içerik ve verimine verimine etkisi

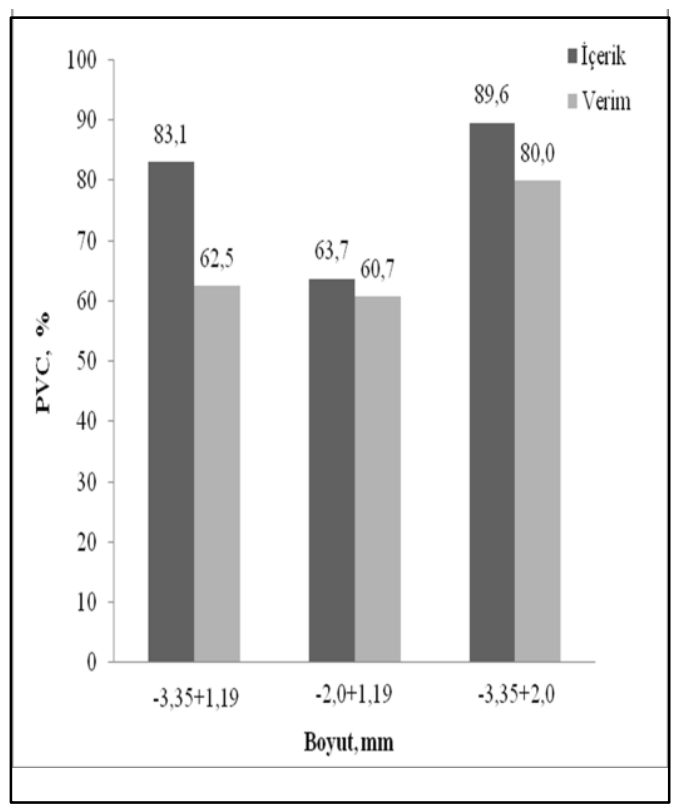

Şekil 12. Tane boyutunun PVC içerik ve etkisi 
Sicaklığın Etkisinin Incelenmesi: Literatür incelendiğinde, bazı çalışmalarda pülp sıcaklığının değiştirilmesinin PET-PVC flotasyonunu olumlu yönde etkilediğine dair bilgiler görülmektedir. $\mathrm{Bu}$ durumu değerlendirmek üzere; sıcaklık değişiminin PET-PVC flotasyonuna etkisi incelenmiştir. Aşağıda verilen sabit koşullarda 3 farklı sıcaklıkta deneyler yapılmış, sonuçlar Çizelge 5'te verilmektedir. Sıcaklık değişimine bağlı olarak PET ve PVC içerik ve kazanma verilmlerine ilişkin değerlendirmeler ise Şekil 13 ve 14'de verilmektedir.

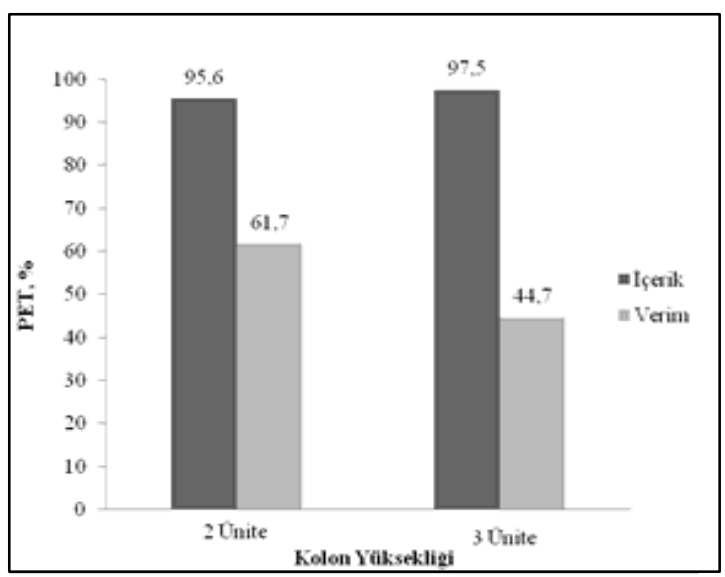

Şekil 13. Kolon yüksekliğinin PET içerik ve verimine etkisi

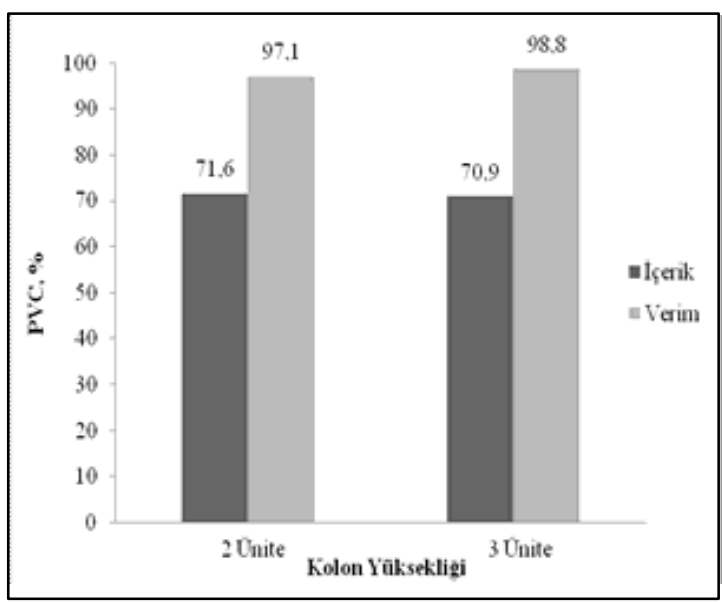

Şekil 14. Kolon yüksekliğinin PVC içerik ve verimine etkisi
Sonuçlar değerlendirildiğinde, pülp sıcaklığının arttırılmasının, PET ve PVC ayırımı üzerinde çok önemli bir değişiklik yaratmadığı, oda sıcaklığında alınan sonuçların yeterli olduğu görülmüştür.

\subsection{Pilot Ölçekli Kolon Flotasyonu Deneyleri}

PET ve PVC plastik atık türlerinin ayrımına yönelik yapılan laboratuar ölçekli çalışmaların 1şığında, pilot ölçekte kolon flotasyonu ünitesi kullanilarak, flotasyon parametrelerinin optimizasyonu hedeflenmiştir. $\mathrm{Bu}$ amaçla, $13 \times 13 \mathrm{~cm}$ kare kesitli ve her bir ünitesi $31 \mathrm{~cm}$ yüksekliğinde, ünitelerin birbirine bağlanması ile kolon yüksekliğinin arttırılabildiği, hava basıncının ve yıkama suyu ayarlarının otomatik kontrol ile yapılabildiği pilot ölçekli kolon flotasyonu ünitesi kullanılmıştır.

Kolon Flotasyonu optimizasyonu çalışmalarında; kolon yüksekliği; hava basınc1; $\mathrm{pH}$; pülpte katı oranı; flotasyonda temizleme /süpürme kademe sayıları ve tane boyutu değişimi detaylı olarak incelenmiş parametrelerin değişimine bağlı olarak elde edilen sonuçlar özet olarak grafiklerde sunulmuştur (Şekil 13-22).

Kolon yüksekliğinin etkisinin incelendiği deney sonuçlarına göre (Şekil 13,14), 2 ünite kullanılması halinde \%95,6 PET içerikli bir ürün \% 61,7 kazanma verimi ile elde edilebilmekte ancak bu ürünün PVC içeriğinin 3 üniteli kolon uygulamasına göre bir miktar yüksek olduğu görülmüş, daha sonraki deneyler 2 ünite yükseklikli kolonda gerçekleştirilmiştir.

Kolonda kabarcık düzeninin ayarlanmasında ve kolon içinde aşırı türbülansın önlenmesinde, hava miktarından çok hava basıncının etkili olduğu görüldüğü için hava basıncının optimize edilmesine yönelik deneyler gerçekleştirilmiştir.

Şekil 15'den görüleceği gibi, hava basıncının artırılması halinde \%98,58 PET (\%1,42 PVC) içerikli bir ürünün \% 46,9 PET kazanma verimi ile elde edilebileceği görülmüştür. 


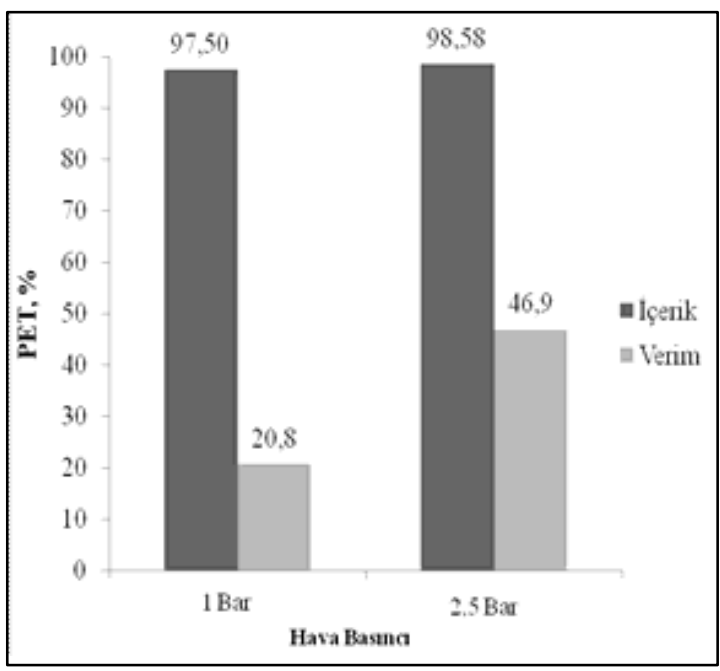

Şekil 15. Hava basıncının PET içerik ve verimine etkisi

pH nın 8'den 10'a yükseltilmesi ile yüzen malzemedeki PET içeriği \%95,6'dan \%99,29'a çıkmış (Şekil 16), PET verimi ise \%61,7'den \%50,3'e düşmüş, batan malzemede ise PVC içeriği \%71,6'dan \%66,70'e düşmesine karşın, PVC verimi \%97,1'den 99,6'ya yükselmiştir (Şekil 17).

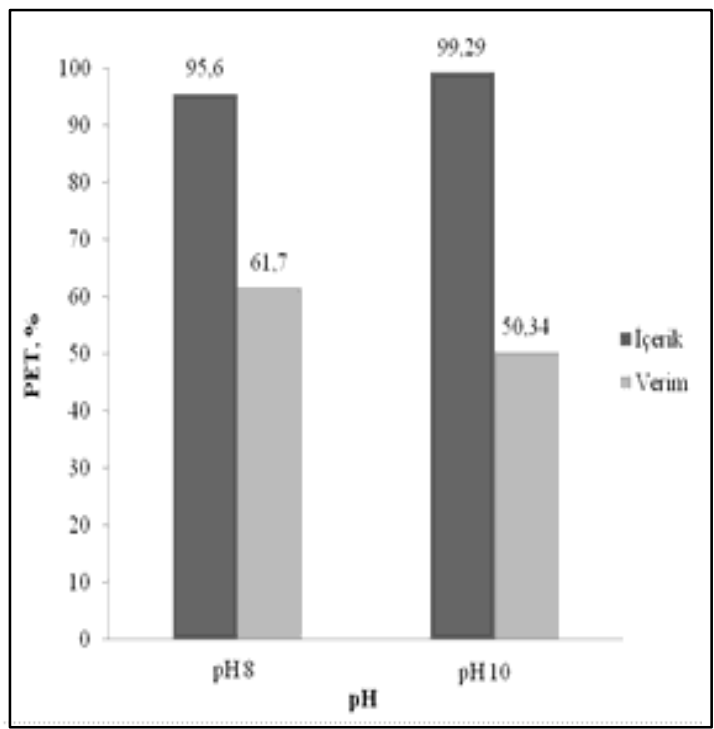

Şekil 16. $\mathrm{pH}$ değişiminin PET içerik ve verimine etkisi

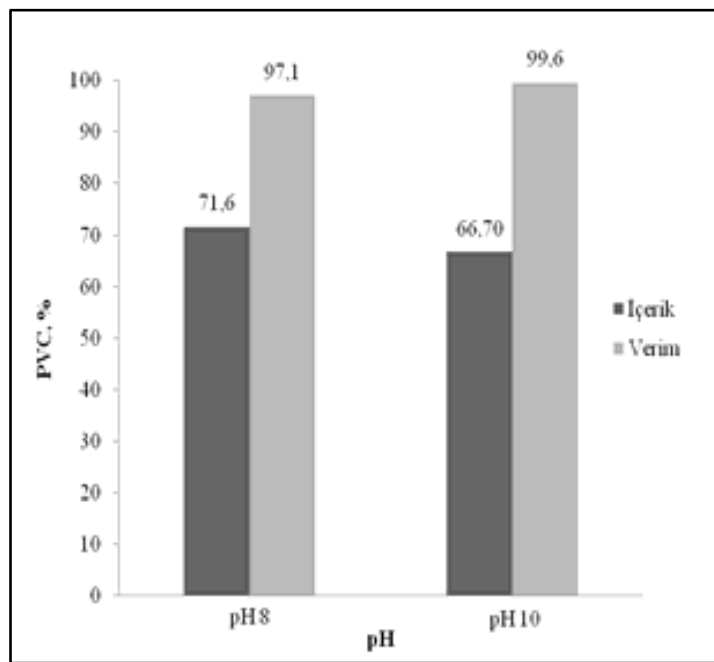

Şekil 17. $\mathrm{pH}$ değişiminin $\mathrm{PVC}$ içerik ve verimine etkisi

Üç farklı katı oranında (\%17, \%28,5, \%32,5) yapılan deneylerden elde edilen sonuçlar değerlendirildiğinde, pülpte katı oranının artışının PET kazanma verimini negatif yönde etkilediği, pilot ölçekli kolonda, katı oranının düşürülmesi halinde, yüzen malzemede PET kazanma veriminin ciddi oranda arttı̆̆ malzemedeki PVC içeriğinin de arttığ1 görülmektedir (Şekil 18, 19).

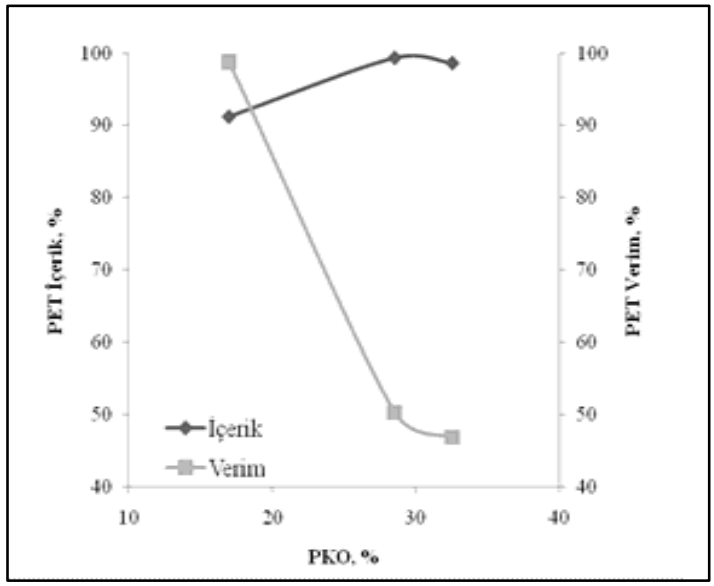

Şekil 18. Pülpte katı oranının PET içerik ve verimine etkisi 


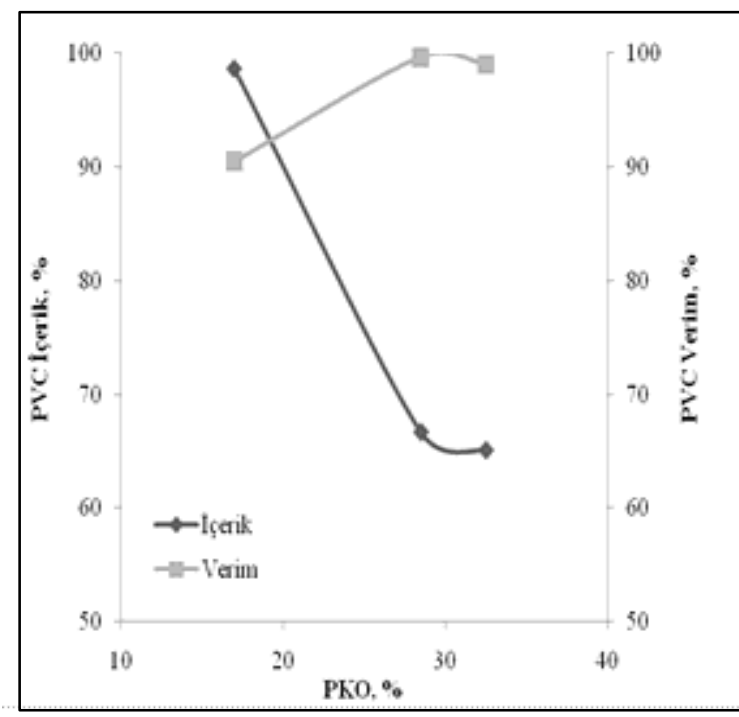

Şekil 19. Pülpte katı oranının PVC içerik veverimine etkisi

Pilot ölçekli kolon ünileri bazında, malzeme besleme boyutunun incelendiği deney sonuçlarına göre de (Şekil 20, 21) PET/PVC içerik ve verimleri açısından en uygun boyut $(-3,35+2,0$ $\mathrm{mm}$ ) olarak teyid edilmiştir.

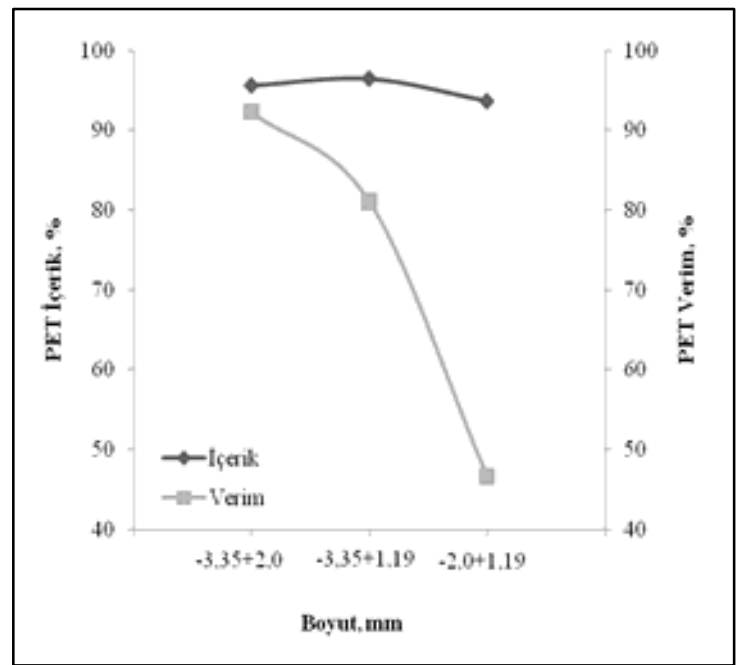

Şekil 20. Boyut değişiminin PET içerik ve verimine etkisi

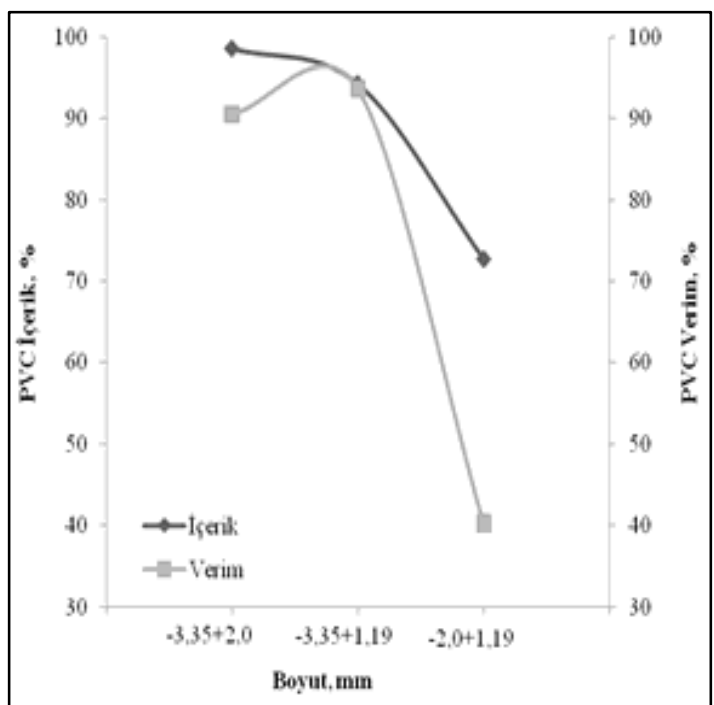

Şekil 21. Boyut değişiminin PVC içerik ve verimine etkisi

Pilot ölçekli kolon flotasyonu optimizasyonunda, son aşamada temizleme ve süpürme kademelerinin flotasyona etkisi incelenmiştir. $\mathrm{Bu}$ aşamada; yüksek PET ve PVC içeriğini yakalayabilmek üzere, $\mathrm{pH} \quad 10$ seviyelerinde tutularak aşağıda verilen sabit koşullarda bir deney gerçekleştirilmiştir. Deneye ait akım şeması Şekil 22'de; sonuçlar ise Çizelge 5'de verilmiştir.

\section{Deney koșulları}

\begin{tabular}{ll}
\hline Boyut & $:(-3,35+2,0 \mathrm{~mm})$ \\
PKO-\% & $: 17,5$ \\
Hava hız1 & $: 450 \mathrm{~L} / \mathrm{sa}$ \\
Hava basıncı & $: 2,5 \mathrm{bar}$ \\
L.Alkali kons & $: 37,5 \mathrm{~g} / \mathrm{t}$ \\
MIBC kons. & $: 5000 \mathrm{~g} / \mathrm{t}$ \\
Kıvam süresi & $: 5+5+5$ dakika \\
Köpük alma süresi & $: 5+5+5$ dakika
\end{tabular}

Temizleme ve süpürme flotasyonları sonrasında yüzen üründeki PET, \%95,6 içerik ve \%92,3 kazanma verimi ile elde edilmiş olup, batan üründe ise \%99,4 saflıkta ve \%90,1 kazanma verimi ile PVC elde edilebileceği görülmüştür (Çizelge 5). 


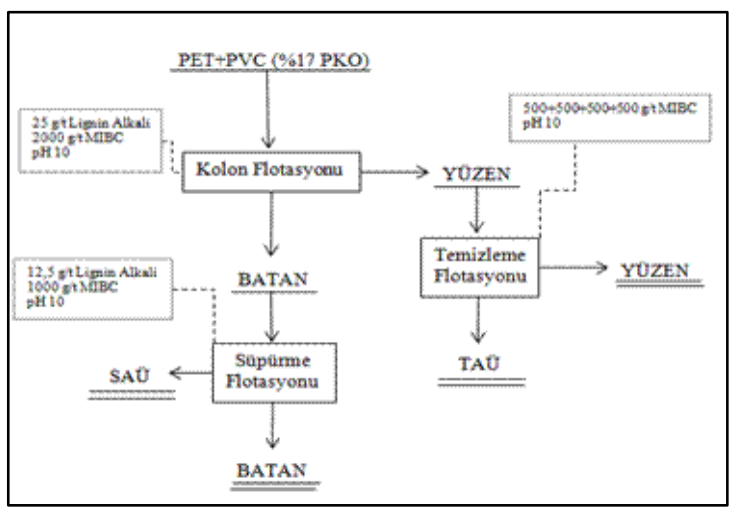

Şekil 22. Temizleme/süpürme kademelerini içeren flotasyon deneyi akım şeması
PET'te $\mathrm{pH} 4,8$; PVC'de ise $\mathrm{pH}$ 3,7 değerinde olduğu belirlenmiştir..

*) Laboratuvar ölçekte yapılan deneyler sonucunda; en uygun parametreler olarak; $(-3,35+2,0 \mathrm{~mm})$ boyut aralığında; oda sicalığında, $\mathrm{pH}=8, \% 17,5$ pülpte katı oran1; $50 \mathrm{~L} / \mathrm{sa}$ hava miktar1, 25 g/t Lignin alkali, $1000 \mathrm{~g} / \mathrm{t}$ MIBC konsantrasyonlarında, tek kademeli flotasyonda, 3 dakika kıvam ve 5 dakika köpük alma süresi sonunda; yüzen malzemede \%90,7 kazanma verimi ile \%81,9 içerikli PET ve batan malzemede \%89,6 kazanma verimi ile \%80,0 içerikli PVC elde edilmiştir.

*) Pilot ölçekte kolon kullanılarak yapılan optimizasyon deneyleri sonucunda; en uygun

Çizelge 5. Temizleme/süpürme kademelerini içeren flotasyon deneyi sonuçları

\begin{tabular}{|c|c|c|c|c|c|}
\hline \multirow{2}{*}{ Malzeme } & \multirow{2}{*}{ Miktar, \% } & \multicolumn{2}{|c|}{ İçerik, \% } & \multicolumn{2}{c|}{ Verim, \% } \\
\cline { 3 - 5 } & & PET & PVC & PET & PVC \\
\hline Yüzen (PET) & 48,4 & 95,60 & 4,40 & 92,3 & 4,3 \\
\hline TAÜ & 5,9 & 55,00 & 45,00 & 6,5 & 5,2 \\
\hline SAÜ & 0,6 & 62,20 & 37,80 & 0,7 & 0,4 \\
\hline Batan (PVC) & 45,1 & 0,60 & 99,40 & 0,5 & 90,1 \\
\hline Toplam & $\mathbf{1 0 0 , 0}$ & $\mathbf{5 0 , 0 0}$ & $\mathbf{5 0 , 0 0}$ & $\mathbf{1 0 0 , 0}$ & $\mathbf{1 0 0 , 0}$ \\
\hline
\end{tabular}

Temizleme ve süpürme flotasyonları sonrasında yüzen üründeki PET, \%95,6 içerik ve \%92,3 kazanma verimi ile elde edilmiş olup, batan üründe ise $\% 99,4$ saflikta ve \%90,1 kazanma verimi ile PVC elde edilebileceği görülmüştür (Çizelge 5).

\section{SONUÇLAR VE DEĞERLENDİRME}

$\mathrm{Bu}$ araştırma kapsamında; PET / PVC ayırımında laboratuvar ve pilot ölçekli kolon flotasyonu üniteleri kullanılarak, seçimli flotasyon koşulları incelenmiş, pilot ölçekli kolon flotasyonu koşullarının optimizasyonu gerçekleştirilmiştir. $\mathrm{Lab}$ ve pilot ölçekte elde edilen sonuçlar bu bölümde özetlenmiştir.

*) Deneylerde kullanılan PET ve PVC'nin zeta potansiyel ölçümlerine göre, eş elektrik noktasının parametreler olarak; $(-3,35+2,0 \mathrm{~mm})$ boyut aralığında; oda sıcalığında, $\mathrm{pH}=10, \%$ 17,5 pülpte katı oranı; $450 \mathrm{~L} / \mathrm{sa}$ hava miktar1; 2,5 bar hava basinc1 37,5 g/t Lignin alkali, $5000 \mathrm{~g} / \mathrm{t}$ MIBC konsantrasyonlarında, birer temizleme ve süpürme kademesi içeren flotasyonda, 5 dakika kıvam ve 5 dakika köpük alma süresi sonunda; yüzen malzemede \%92,3 kazanma verimi ile \%95,6 içerikli PET ve batan malzemede \%90,1 kazanma verimi ile \%99,4 içerikli PVC ürünlerinin elde edilebileceği görülmüştür.

\section{KAYNAKLAR}

1. Alp, S., 2003. İstanbul Ticaret Odası Plastik Sektör Raporu, İstanbul.

2. Savaşçı, Ö. T., Uyanık, N., Akovalı, G., 2002. Ana Hatları ile Plastikler ve Plastik Teknolojisi, PAGEV Yayınları. 
3. Paci, M., La Mantia, F. P., 1999. Influence of Small Amounts of Polyvinylchloride on the Recycling of Polyethyleneterephthalate, Polymer Degradation and Stability, Cilt.63, s.11-14.

4. Singh, B. P., 1998. Wetting Mechanism in the Flotation Separation of Plastics, Filtration \& Separation, s.525 -527.

5. Sevencan, F., Vaizoğlu, S. A., 2007. PET ve Geri Dönüşümü, TSK Koruyucu Hekimlik Bülteni, Cilt.6 (4), s.307-312.

6. Kıralp, S., Özkoç G., Erdoğan, S., Çamurlu, P., Doğan, M., Baydemir, T., 2007. Modern Çağın Malzemesi Plastikler, ODTÜ Bilim ve Toplum Kitapları Dizisi ODTÜ Yayıncılık.

7. Güler, Ç., Çobanoğlu, Z., 1997. Plastikler, Sağlık Projesi Genel Koordinatörlüğü.

8. Url-4 <http://www.kimyamuhendisi.com>, alındığg tarih 09.01.2010.

9. Shen, H., Pugh, R. J., Forssberg, E., 2002. Floatability, Selectivity and Flotation Separation of Plastics by Using a Surfactant, Colloids and Surfaces A: Physicochemical and Engineering Aspects, 196, s.63-70.

10. Dinger, P., 1992. Automatic Microsorting for Mixed Plastics, BioCycle, Cilt.33(4), s.79-80.

11. Drelich, J., Payne, T., Kim, J. H., Miller, J. D., 1998. Selective Froth Flotation of PVC from PVC/PET Mixtures for the Plastics Recycling Industry, Polymer Engineering and Science, 38(9) s. 1378-1386.

12. Marques, G. A., Tenório, J. A. S., 2000. Use of Froth Flotation to Separate PVC/PET Mixtures, Waste Management, 20, s. 265269.

13. Drelich, J., Kim, J. H., Payne, T., Miller, J. D., Kobler, R. W., 1999. Purification of Polyethylene Terephthalate from Polyvinyl Chloride by Froth Flotation for the Plastics (Soft-Drink Bottle) Recycling Industry, Separation and Purification Technology, 15, s. 9-17.

14. Shen, H., Forssberg, E., Pugh, R. J., 1998. A Review of Plastics Waste Recycling and the Flotation of Plastics, Resources, Conservation and Recycling, 25, s. 85-109.

15. Le Guern, C., Conil, P., Houot, R., 2000. Role of Calcium Ions in the Mechanism of Action of a Lignosulphonate Used to Modify the Wettability of Plastics for their
Separation by Flotation, Minerals Engineering, 13 (1) s.53-63.

16. Shen, H., Forssberg E., Pugh R. J., 2001. Selective Flotation Separation of Plastics by Particle Control, Resources, Conservation and Recycling, 33, s.37-50.

17. Pascoe, R. D., O’Connell, B., 2003. Flame Treatment for the Selective Wetting and Separation of PVC and PET, Waste Management, 23, s.845-850.

18. Takoungsakdakun, T., Pongstabodee, S., 2006. Separation of Mixed Post Consumer PET-POM-PVC Plastic Waste Using Selective Flotation, Separation and Purification Technology, 54, s.248-252.

19. Yenial, Ü.. 2007. PET ve PVC Artıklarının Kolon Flotasyonu ile Ayrılmasında Değişik Plastikleştirici Reaktiflerin Etkisinin İncelenmesi, Lisans Tezi, İTÜ Maden Fakültesi Maden Mühendisliği Bölümü.

20. Özdilek, C. 2009. PET ve PVC Artıklarının Kalsiyum Lignosülfonat ve Lignin Alkali Tipi Plastikleştirici Reaktifler Kullanılarak Seçimli Olarak Ayrılmasının Araştırılması, Lisans Tezi, İTÜ Maden Fakültesi Maden Mühendisliği Bölümü.

21. Plastik Atıkların Geri Kazanımına Yönelik Uygun Flotasyon Proseslerinin Geliştirilmesi, 2010. İTÜ Maden Fakültesi, Cevher Hazırlama Müh. Bölümü, TÜBİTAK MAG, 1001 Araştırma Projesi, Proje No:108M042.

22. Kılıç, M., 2010. Katkılı PVC ve PET Atıklarının Seçimli Olarak Ayrılmasına Yönelik Kolon Flotasyonu Parametrelerinin Belirlenmesi, Yüksek Lisans Tezi, İTÜ Maden Fakültesi Maden Mühendisliği Bölümü.

23. Güney A., Atak S., 1993. Flotasyon ve Flokülasyon Cevher Hazırlama Teknolojisindeki Yeni Gelişmeler, konulu Meslek İçi Eğitim Semineri İTÜ Maden Fakültesi İstanbul, 6-10 Mayıs 1991, 1-30.

24. Öteyaka, B., Soto, H., 1992. Modelling of Negative Bias Column for Coarse Particles Flotation, 4. Uluslararası Cevher Hazırlama Sempozyumu Bildirileri, Ekim, Antalya.

25. Jameson, G., J., 1998. A New Concept in Flotation Column Design, Column Flotation 88, Sastry, K., V., S., (ed.), SME. 
26. Finch, J.,A., Dobby,G.,S., 1991. Column Flotation: A Selected Review, Part II; Volume 4, Issue 7, Pages 911-923 Minerals Engineering, Elsevier Ltd.

27. Amelunxen R., L., 1985. The Mechanics of Operation of Column Flotation Machines, Proc. 17 th Meeting of the Canadian Mineral Processors,C.I.M., Ottawa, Jan., pp 13-31. 
